\title{
REVIEW ESSAY: BORDERS AS PRACTICES AND PROCESSES
}

De Genova, Nicholas (ed.). The Borders of 'Europe': Autonomy of Migration, Tactics of Bordering. Duke University Press. 2017. 376 pp. ISBN: 978-0-8223-6888-5 (cloth); ISBN: 978-0-8223-6916-5 (paperback).

Demetriou, Olga and Rozita Dimova (eds). The Political Materialities of Borders: New Theoretical Directions. Manchester University Press. 2018/2019. 152 pp. ISBN: 978-1-5261-2385-5 (hardback); ISBN: 978-1-5261-2592-7 (E-book).

$\mathrm{W}$ hen studying human mobility-from refugee camps to tourism, displacement to manual labour-we find ourselves addressing borders. Borders are meant to create and reflect division, manage and deter movement, define the permissibility of various forms of mobility, and establish various racial, economic, and political hierarchies. Borders are drawn, performed, enacted, enforced, and transgressed. They connect, separate, and demarcate. People live within and across various borders and boundaries, they orient towards and (re) produce, as much as challenge and (re)negotiate, them. The role of borders in the perception of our surroundings, as much as in our political imaginaries, has dramatically transformed over the past decades. The emergence of new sovereign states, the end of the Cold War, the intensifying political and economic project of the European Union, the various new poles of world power, global capitalism, the War on Terror, and unprecedented levels of displacement around the globe have all brought about new configurations of bordering and border crossing. And as borders and physical border walls have proliferated around the world, so has the study of borders become an increasingly diversified endeavour. The question is not simply what borders do, but equally, what makes a border? Borders delineate territory, control the speed and volume of crossing humans and goods, and reinforce the division between the wanted and the unwanted, those who belong and those who do not. Sometimes they acquire a physical form as fences and checkpoints, follow particular topographies, or are born out of a line drawn on a map. Borders of nation-states tend to possess these qualities or they are enforced, through violence and political repression, as if they had such qualities. However, borders are ideas or ideologies-of nations, states, economies, belongings, and distinctions. They are equally immaterial and invisible, only manifested as relations of peoples and things.

Critical analyses of borders have increasingly dislocated 'the border' from a geographical fixity and visibility. These two books, one edited by Nicholas De Genova and the other by Olga Demetriou and Rozita Dimova, continue in this direction, albeit from different points of departure. The Borders of 'Europe' looks at borders primarily as practices of bordering such as passport and visa regimes and police enforcement. It also highlights how these various forms of control are being subverted. The Political Materialities of Borders 
theorises the ontological qualities of borders as processes, as an interplay between the material and the immaterial. Combined, there is a dual modality at work: what generates a border and what, in turn, are borders generative of? Both edited volumes have a focus on Europe. For the former it is Europe and its politics and tactics of bordering against migration. ${ }^{1}$ For the latter it is various border encounters in Europe's southeast, in what is roughly the Balkans region. The theoretical and ethnographic implications of both, however, have a wider reach and applicability. Both books address and illuminate important qualities and roles various borders acquire and manifest in the everyday lives of people who encounter them-and how these borders come about in the first place. Understanding the violence brought about by borders, as analysed in The Borders of 'Europe', is imperative virtually anywhere where human mobility is framed as a political, economic, or socio-cultural threat. Thinking about how and what borders manifest, as proposed in The Political Materialities of Borders, is equally useful whenever people orient towards or seek to define borders. The focus on Europe comes, however, with a particular caveat in that it privileges the state as an entity that will always figure in the border-making process in one way or another. Still, neither one of the edited volumes claims to be establishing a universal theory of the Border', but examines borders and bordering in a particular form.

The Borders of 'Europe' consists of an introduction and eleven original articles. In one way or another, the articles all have a connection to the analytical perspectives broadly defined as the Autonomy of Migration. At the heart of this approach is the notion of excess. This notion is two-sided: on the one hand, the technologies and practices to manage mobility increasingly employ excessive force, but on the other hand, migratory movements are framed as something 'too much' for these border regimes. Migration controls, from documents, border fencing, and surveillance to dehumanising border 'spectacles', may close routes of migration and cause great harm and injury in the process, but ultimately people compelled or forced to move will come to occupy a space-crevices, paths, and narrow alleyways-of uncontrollability. People find new ways to cross, formulate political strategies to overcome legal predicaments, and adjust their strategies in accordance to the new technologies put in place to deter them. Furthermore, the contributions to this volume highlight how European states operate frequently at the edges of legality, consistently violating the very values they purport to be upholding. In his introduction to the volume, De Genova situates the 'crisis' of migration as the crisis of the European nationstates. He notes that the "crisis of border control and migration management may therefore be seen to be a crisis of sovereignty that is repeatedly instigated, first and foremost, by diverse manifestations of the autonomous subjectivity of the human mobility itself' (p. 13). He argues that the source for the 'crisis' is the struggle over the borders of Europe, the tension between the border regime, and the spatial claims made by the migrants exercising their elementary freedom of movement (p. 17). The articles included in the book, therefore, locate the concept of 'Europe' in the processes of demarcation; they stress how 'Europe' is constituted by its colonial character, racial imaginaries, and, ultimately, by those it tries to keep out of the territory it claims its own. At the same time, the authors note, current policies and events cannot be understood by looking at Europe alone. Instead, there is a global political and social context to the events analysed in the volume, which rises from the inextricable interconnectedness of Europe to Africa and the Near East. 
In Chapter 1, “The Secret is to Look Good on Paper": Appropriating Mobility within and against a Machine of Illegalization', Stephan Scheel analyses the Schengen visa regime as a bordering practice. An apparatus comprised of institutionalised distrust and hostile bureaucracy, it is, nonetheless, challenged by aspiring migrants through what he refers to as 'appropriation'. He shows how, through their suspicion and seemingly unpredictable policies, the visa-issuing embassies are creating the very 'illegality' the system is supposedly set up to combat (pp. 44-45). Scheel's contribution is an important analysis of the dislocation of borders from geographical fixity to bureaucratic practices situated outside the nation-states themselves. By attempting to move beyond the concepts of agency and resistance, the article explores how aspiring migrants appropriate the Schengen visas; through fake documents, fraud and various other forms of subversion, they appropriate the system's qualities to their own ends.

In Chapter 2, 'Rescued and Caught: The Humanitarian-Security Nexus at Europe's Frontiers', Ruben Andersson analyses the dislocation of the EU borders in the form of externalisation of enforcement and the paradoxical coexistence of humanitarian and 'securitarian' approaches within the border regime. He describes how the Spanish Guardia Civil not only patrol the Melilla border fence against Morocco but how they cooperate with various African colleagues on land and sea. Crucial to his contribution is how militarised enforcement efforts are increasingly framed as search and rescue operations, as 'helping people'. What Andersson calls a 'humanitarian impulse' has defined the logic of many of the initiatives to intercept and expel migrants to either countries of residence or transit. Staying on the topic of externalisation and the interconnections between policing and humanitarian functions, Charles Heller and Lorenzo Pezzani, in Chapter 3, 'Liquid Traces: Investigating the Deaths of Migrants at the EU's Maritime Frontier', continue with the critical analysis of the Mediterranean migratory routes and their enforcement. By building on the Forensic Oceanography project 'Left-todie Boat', they argue that 'migrants die not only at sea but through a strategic use of the sea' (p. 96). Through the growing militarisation of the Mediterranean Sea, the conditions for crossing have been made increasingly perilous, while search and rescue capacity has been used tactically and often sparingly, to effectively create what is a 'liquid trap' (p. 113).

Chapter 4, 'The Mediterranean Question: Europe and Its Predicament in the Southern Peripheries', by Laia Soto Bermant brings the reader back to Melilla, Europe's land border with Africa. Tracing not only the history of bordering practices, but also the various local histories of trade, labour mobility, and trafficking, she argues that the struggle for space extends beyond and cuts across national boundaries. She points out how in the 'northern' political imaginaries, Spain is in itself a periphery of Europe, not least through its historical encounters with the Muslim world, but, at the same time, the country is construed by the current need for 'effective management' of migration as distinctly European in comparison to those peoples and societies outside the Melilla triple-fence. Coming back to De Genova's theses laid out in the introduction to the volume, she argues that bordering of 'Europe' is simultaneously a capitalist and a racialised project, which seeks to legitimise particular distribution of resources and access.

In Chapter 5, 'Europe Confronted by Its Expelled Migrants: The Politics of Expelled Migrants' Associations in Africa', Clara Lecadet 
analyses the political activism of those deported back to their countries of transit or original residence. She argues that expelled migrants' associations constitute a form of political action and agency outside the border regimes-or, in any case, are exerting pressure on the existing regimes-but, at the same time, a number of them are being incorporated, with various degrees of compliance, to the framework of assisted return and formal humanitarian reception. Revealing, again, the tension between policing and aid characteristic of European bordering practices, Lecadet discusses how rejection can become a politically significant catalyst for participation and how these political projects also work sometimes alongside, sometimes against, the internationalisation and externalisation of the measures and techniques of migration control. Glenda Garelli and Martina Tazzioli, in Chapter 6, 'Choucha beyond the Camp: Challenging the Border of Migration Studies', analyse another contradictory tension between policing and aid by exploring the Choucha refugee camp abandoned by both the UNHCR and the local authorities in Tunisia, near the border to Libya. Through the concept of 'a camp after the camp', they discuss a 'retreat of the humanitarian government' (p. 177) and its function in the government of migration. Equally important, they argue, is the role such practices had for state-building in Tunisia through a kind of inclusive exclusion, as the residents left behind were abandoned but simultaneously governed by being subjected to constant threat of detention and deportation as 'undocumented'.

The next two chapters, "Europe" from "Here": Syrian Migrants/Refugees in Istanbul and Imagined Migrations into and within "Europe" by Souad Osseiran and 'Excessive Migration, Excessive Governance: Border Entanglement in Greek EU-rope' by Maurice
Stierl, deal with particular temporalities in migratory processes and their enforcement. Osseiran's contribution analyses a particular way of looking past the border, the expectations and plans Syrians in Turkey have for their journey to Europe. These include which countries to go to and which routes to take. Through the knowledge they have built and the rumours they hear, Syrians had developed particular imaginaries-that is, connections to possibilities and means-regarding countries of transit and countries of final residence. Through a case of an extended Yezidi family, Stierl shows how various migratory routes and policies direct and penalise mobility. Starting with the main interlocutor, a man stuck in an illegalised position in Greece despite having legal residence in Germany, he explores how the EU border regime's hold on mobile individuals is far more multifaceted than would appear and shows how its reach extends beyond the act of crossing and the process of regularisation. In the same vein, temporalities and circulation enforced by borders and bordering are at the heart of Chapter 9, 'Dubliners: Unthinking Displacement, Illegality, and Refugeeness within Europe's Geographies of Asylum', by Fiorenza Picozza. She documents how migrants from Afghanistan living in Italy are both emplaced and compelled to move by the Dublin Regulation which stipulates that asylum claims should be processed by the EU member state where the applicant was registered for the first time. The 'Dubliners' force us to rethink categories such as 'migrant' and 'refugee' in what Picozza calls the 'Dublin space' (p. 253).

The final two chapters of the volume deal with the role of activism and civic participation in (re)negotiating bordering and illegalisation. In Chapter 10, 'The "Gran Ghettò": Migrant Labor and Militant Research in Southern Italy', Evelina Gambino looks at how undocumented 
labour in the Capitanata Plain, in Puglia, Italy, comes to embody particular configurations of bordering and migrant policing, deeply rooted in the needs of agricultural industry of the region. Gambino further elaborates on how the precarious workers, together with activists, have organised themselves and formed networks for action and knowledge sharing to counter the labour exploitation and illegalisation created by the Italian state. In the final chapter, "We Want to Hear from You": Reporting as Bordering in the Political Space of Europe', Dace Dzenovska analyses the role of citizens' reporting in constructing 'Europeanness' and enforcing national identities. By drawing from her work in Latvia, which began constructing itself as both Latvian and European after the 1991 independence from Soviet Union, and more recent developments in Britain, she argues that reporting on and surveilling one's neighbours, colleagues, or even family members in liberal states constitute a form of 'securitised freedom'. These political and social relations construct divisions between a good citizen and failed citizen, citizen and non-citizen, European and the non-European, but simultaneously undermine these categorisations, as those doing the reporting to the state cannot themselves be so easily categorised as citizens, or even 'Europeans'.

If The Borders of Europe analyses borders as something materialised through enforcement, the contributions to The Political Materialities of Borders, in turn, analyse and think about borders and bordering from a more ontological point of view. They argue that borders are mediations between the material and the ideological, or the non-material more generally. They are created, recreated, and brought to life from the interconnectedness of state as a material project and state as an abstraction. Where The Borders of Europe focus primarily on the EU borders as the products of the ideologies of colonialism and neoliberal capitalism, the contributors to The Political Materialities of Borders look at how borders actually are both ideology and matter. For them, politics produce and reform borders, but the materiality of borders itself, equally, produces new politics and immateriality. For example, in Chapter 1, their introduction to the edited volume, Olga Demetriou and Rozita Dimova argue that the materiality of borders is a consolidation and reproduction of political ideology; as ideologies shift and change, so do borders. There are material conditions, physical topographies, and social relations prior to a border, or a particular instantiation of a border, and they change as new forms of subjectivities are brought about by the borderwork. Materiality is enmeshed with the abstract (p. 10). They propose to study borders not as manifestations of politics but as the creative point of inseparability of the material and the abstract which brings about the political: 'The reading of a paper as "law" is invested with powers of the state, knowledge, policing, and so on. However, it is not that "paper" and "law" stand on either side of the material nonmaterial divide.' (p. 13)

The volume begins with Olga Demetriou's chapter 'Materiality, Imbrication, and the Longue Durée of Greco-Turkish Borders'. Through the term 'imbrication', the overlapping structure of roof tiles or fish scales that form a single whole, she explores the Greco-Turkish borders and the projects of nationalistic bordering at two geographical locations, the Evros River and Cyprus, which is divided by the Green Line. Her argument is that more than simply demarcating terrain and governing the acts of crossing, borders manifest layering in time and space. 'Imbrication' becomes here both a metaphor and an analytical method to make sense of and describe the material, the 
immaterial-or, the non-material-and the political in the creation and function of the border.

In Chapter 3, 'Memory as Border Work: the 2008 Italy-Libya Friendship Treaty and the Reassembling of Fortress Europe', Chiara De Cesari analyses the colonial forgetting and the enforcement of EU borders involved in the Italy-Libya Friendship Treaty between Muanmar Al-Qadhafi and the Italian government lead by Silvio Berlusconi. She argues that important in the wording and the ensuing media attention to the treaty was the omission of acknowledgement of the depth and nature of colonial atrocities inflicted on the Libyans by Italy in what De Cesari calls, following Ann Stoler, a 'colonial aphasia'. The treaty, which would see Libya receiving 6 billion dollars in total and simultaneously give Italian companies lucrative business opportunities was, she argues, crucially about Libya preventing migrants from leaving the country and heading to Italy. With the treaty, therefore, European borders come to be constructed not only through the liquid border between Italy and Libya, but equally through the memory, or the omissions within that memory, of Italy's colonial past. Additionally, the logic of the treaty has been operationalised even after its collapse with the war in Libya in increased militarisation of the Mediterranean Sea.

The next two chapters of the volume, 'Ontologies of Borders: the Difference of Deleuze and Derrida', by Tuija Pulkkinen and 'Lines, Traces, and Tidemarks: Further Reflections on Forms of Border' by Sarah Green, further theorise how we can conceptualise borders. Through the work of Gilles Deleuze and Jacques Derrida, Pulkkinen analyses two different ontological stances on the creation of borders. The Deleuzian approach, she argues, would reflect a philosophical idea of omnitemporality, removed from particular historical and spatial context, while the Derridean approach would look at particular actions, events, and histories involved in making the border. Pulkkinen examines the creation of two borders, a geopolitical 1809 border which heralded the creation of a Finnish identity under the Russian Empire and a border in the creation of knowledge, which made the distinction between a homosexual and a non-homosexual. In her chapter, Sarah Green seeks to reconceptualise borders not completely removed from the concept of lines, but, following Marilyn Strathern as well as Tim Ingold's discussion of lines and meshwork, argues that borders are an attempt to cut through the mess and create a 'thing' amidst the potentially endless flow of connections, networks, and wandering. Green evokes the concept of a 'trace' to highlight how material evidence implies the existence of something larger, yet invisible; like breadcrumbs imply the existence of the now invisible loaf, so do checkpoints and walls imply the existence of a border. Finally, building on her discussion of a 'trace', Green brings forth the concept of 'tidemark' to make sense of 'border-ness' in all of its historically contingent, visceral, imagined, and political qualities.

Chapter 6, 'Materializing the Borderas-Line in Sarajevo', by Stef Jansen, offers an interesting point of comparison to Green's contribution. While Green, among the many contemporary borders she addressed, described the 'one-sided' border in Cyprus, Jansen examines a border which one side wishes to fade away and the other to harden to become a proper border. Exploring the history and the maintenance of a 'border line', literally drawn on the map, in Dobrinja, Sarajevo, Jansen looks at different instances of line-drawing. Reflecting 'two incompatible sovereignty claims' (p. 96), of Bosnia and Herzegovina and the Republika 
Srpska, he shows how the border is still in the process of being drawn despite already manifesting multiple layers of bordering, much like in the process of imbrication evoked by Demetriou in her contribution. He explores how the two projects of sovereignty and territorial integrity also structured the everyday lives of people living on both sides of the line that cut through the neighbourhood. Jansen's argument ultimately is that if we say that 'a border is not simply a line drawn by the state', the focus should be on the word 'simply' instead of the word 'not'.

The last two chapters of the book, Eleni Myrivili's 'Borders as Ghosts' and Rozita Dimova's 'Materialities of Displacement: Borders in Contemporary Macedonia', both approach the location of a border in novel ways. Drawing from the Derridean concept of 'spectre' and her field site at the Prespa Lake at the intersection of different nationstate borders, she argues that borders are ghosts; state power haunting us even when we cannot see it, like Michael Taussig's 'nervous system' 'switching between ordered system and unstable agent of terror' (p. 113). She describes how the secret police can suddenly stop us for inspection or when, seemingly out of nowhere, the military springs to action the moment we cross the border. In her contribution, Rozita Dimova explores how the material structures of a history of conflicts at the Greek-Macedonia borders are dislocated from the actual border zones and instead appear in the monuments and construction projects in Skopje, the Macedonian capital. She shows how the borders of the nation-state and the nation are affirmed and claimed by this public spending on refurbishing and construction projects in the city centre. Building on Sarah Green's conceptualisations in Chapter 5, she writes how 'the aesthetic remodelling of central Skopje is both a trace of the conflict with Greece that results in a tidemark, and a ripple effect swelling towards the actual borders'. Borders are here made in relation to the conflict with Greece, the socialist and Ottoman past, and in the project of national 'revival'.

Coming from very different points of departure, The Borders of Europe and The Political Materialities of Borders complement each other. The ethnographic depth of the former and its emic-level involvement with the lives of the people encountering the border can only benefit from the theoretical challenges posed by the latter, and vice versa. Read together, they highlight how borders are both practices and processes. Both edited volumes make important contributions to our understanding of the concept of borders. Eloquently, yet systematically, they describe how what function borders are expected to perform - and what kind of routines, responses, and encounters they actually have a role in - may vary considerably. As the contributors to The Borders of 'Europe' show, practices of bordering kill, dehumanise, and illegalise the various groups of people they are targeting. However, simultaneously, this precariousness engenders and empowers different forms of resistance and subversion. Another important point the authors make is that borders and bordering practices also constitute forms of precarity, as they enforce 'illegality' and 'undocumentedness' on individuals or entire groups of people. At the same time, as the contributors to The Political Materialities of Borders note, borders are only partially manifestations of existing state apparatuses; they also produce new politics and political imaginaries. Much like law, borders are neither clearly material nor obviously immaterial. They are also in motion, over time and space. 
Both books, therefore, develop further the notion that borders are definitely something more than mere lines drawn on map or markers of geopolitical power relations sanctioned by neoliberal capitalist economy and national and international legal bodies. In a meshwork, they constitute, and are constituted by, for example, local histories, socio-political configurations, trade routes, kinship connections, and ideologies. Finally, what both books also establish in various interesting ways is that borders are not simply 'things' as such even if they take on material forms, but also the result of human action and interaction. The police, the humanitarians, the military, the traders, the smugglers, the crossers, and the deported are not merely the 'products' of various bordering practices and processes, but, equally, what actually establish or come to embody the location of the border-sometimes far from the line drawn on the map.

\section{NOTES}

1 Various different expressions exist, such as 'refugees and migrants' 'migrant/refugee', stemming from the two conflicting definitions of migrants (in policy, media, and academic research): the inclusive one, where refugees are included in the category of the 'migrant', and the exclusive one, advocated for by for example the UNHCR, which addresses refugees as a separate political and legal category distinct from migrants. The reality not conforming to sharp distinctions and the reasons compelling or forcing people to move being often far from clear-cut, I use the former inclusive one instead of the latter.

VILLE LAAKKONEN Ph.D. Cand

DOCTORAL RESEARCHER,

SOCIAL ANTHROPOLOGY

FACULTY OF SOCIAL SCIENCES

TAMPERE UNIVERSITY

ville.laakkonen@tuni.fi 